\title{
GOVERNMENT AND RANGE MANAGEMENT IN IRAN (POLICY, LAWS AND PLANS)
}

\author{
ZOHDI, M. ${ }^{1}-$ ARZANI, H. ${ }^{2 *}-$ JAVADI, S. A. ${ }^{1}-$ JALILI, A. ${ }^{3}-$ KHORSHIDI, G. ${ }^{4}$ \\ ${ }^{I}$ Department of Range Management, Science and Research Branch, Islamic Azad University, \\ Tehran, Iran \\ ${ }^{2}$ College of Natural Resources, Tehran University, Tehran, Iran \\ ${ }^{3}$ Research Institute of Forests and Rangelands, Tehran, Iran \\ ${ }^{4}$ Department of Management and Accounting, Martyr Beheshti University, Tehran, Iran \\ *Corresponding author \\ e-mail: harzani@ut.ac.ir \\ (Received $13^{\text {th }}$ Mar 2018; accepted $17^{\text {th }}$ Jul 2018)
}

\begin{abstract}
Through laws, policies and plans, governments manage natural ecosystems, including rangelands. According to the political and economic approaches, scientific achievements and the ecological and social developments, the mentioned laws and policies must be developed and updated. Investigation of the effects of these measures can play an important role in the improvement of management processes and updating laws and policies. Reduced level and trend of destruction affirms that the government's actions of Iran in rangeland management are not effective enough and need to be reassessed. The present research was carried out aiming at investigating the effectiveness of laws, policies and plans on rangeland management based on a survey of rangeland management specialists. In this research, results and data have been collected based on questionnaire from experts in executive department (Forest, Rangeland and Watershed Organization), Natural resources research specialist and university faculties. Given the facts that a large number of contestants were available and based on the type of this research, the non-probability sampling method (judgment sampling) has been used. Data were analyzed through using SPSS software, descriptive and inferential statics of $\left(\mathrm{X}^{2}\right)$ and KruskalWallis test. The total number of specialist rangers in this study was 268 people. The results show that A significant part of the experts participating in this research believe that the nationalization of rangelands has had profound effects on rangeland management systems. In addition, a large number of respondents believe that government policies in relation to rangeland need to be revised and redevelopment plans should also be prepared and implemented in accordance with ecological and social conditions.
\end{abstract}

Keywords: laws, land reform, nationalization of rangelands, rangeland survey, grazing permit, rangeland management plan, rangeland management policy, effectiveness, Iran

\section{Introduction}

In the Middle East, livestock breeding and rangeland management flourished thousands of years ago, and rich indigenous knowledge has existed along with deep cultural roots in relation to rangelands in various areas. Based on investigation of historical documents, Javanshir (1999) states that the terms related to the pastoralism are seen in the life of the ancient Persian societies; all of which confirms the importance and development of livestock and range management in the ancient history of this part of the world. This is despite the fact that the science of rangeland management has a relatively short history and only dates back to the early twentieth century. What is currently known as the science of range management first appeared in the US. Holechek et al. (2004) state that in the United States, livestock grazing and 
its impacts on the degradation of pastures were brought into attention back at late 19th century.

Anyway, during the past century, due to population growth, agricultural land development and the expansion of residential areas, the pressure on rangelands has increased dramatically and in many parts of the world the pastures have been degraded and reduced in size. Therefore, many governments have tried to reduce the degradation of pastures and control the grazing process. Through laws, policies and plans, governments manage natural ecosystems and try to improve them during time based on political and economic approaches, scientific achievements, ecological transformations and social changes. Therefore, studying the effectiveness of policies used in rangelands management can play a very important role in guiding governments to improve management processes and update the rules and regulations. Considering the decrease in the area and quality of rangelands, it can be concluded that the government's programs in rangeland management have not been effective enough. So, in order to investigate this issue, some of the laws, policies and plans of rangeland management have been investigated in this research and analyzed based on the experts opinions.

\section{Rangeland areas of Iran}

The area and quality of rangelands can be an appropriate indicator in the assessment of the success or failure of management programs and measures. Considering the rangeland areas, Squires et al. (2017) state that more than 85 percent of Iran's surface area is arid and semi-arid, and from the total land area, 84.8 million ha, equivalent to 51.4 percent, consists of pastures. It argued by Farahpour and Marshall (2001) that only 9.3 million ha of pastures $(10.3 \%)$ are in good conditions and 37.3 million ha are in moderate conditions (41.4\%), and the remaining, 43.4 million ha, have poor condition (48.3\%). Eskandari et al. (2009) provide the following estimates for the rangeland areas. Their report is important because Eskandari was, at the time, the Director General of the Forests, Rangelands and Watershed Management Organization (FRWO). This rangeland Technical Bureau, which is the main provider of rangelands management and implementer of government policies of Iran, is part of the FRWO, which is also one of the deputies of the Ministry of Agriculture Jihad. Therefore, the above-mentioned report can be considered as a formal report by the government.

1. Niknam (1968) reports the rangeland areas to be 100 million ha.

2. The American FMC Company (1974) reported the rangeland areas to be 90 million ha.

3. The rangeland technical Bureau (FRWO) in 1996, the rangeland area is 90 million ha.

4. Based on digital satellite images, land maps, and vegetations of Iran, FRWO reported the rangeland areas to be 86.1 million ha in 2005 and 84.7 million ha in 2008.

Among the most important causes of the decline in rangeland areas we may refer to increase in population and demand for food, the grazing pressure of livestock, change of use, drought, desertification and government policies. Karimi and Karami Zahkardi (2016) stated that regarding the changes in rangeland areas, despite the importance of rangelands, studies have shown that in the past years, the quality and grading 
rangelands have undergone changes that were due to inappropriate human activities and most of these degradations included rangelands of good and moderate quality. Therefore, these changes can confirm the failure of government policies and programs in the management and conservation of rangelands.

\section{Rules and regulations related to rangeland management}

Araghi et al. (1998) state that after the Constitutional Movement, conservation of forests was considered important by legislators. Added was the concern for maintaining the rangelands. In 1960, the issue of rangelands was directly and clearly observed along the forests in the law of forests and rangelands for the first time. The approval of the nationalization of forests and rangelands (in 1963) declared the rangeland as public property belonging to the state. Shamekhi (2009) stated that Islamic jurisprudence is the main legislative basis, and that the Islamic Revolution of 1979 created a new stage in legislation. Also, the Islamic jurisprudence had a great influence on current laws. Motamedi et al. (2007) state that in 1967, after the enactment of "the Law on the Conservation and Use of Forests and Rangelands", and in concordance with the provisions of the Note 1 of the Article 3 of this Law, "the use of rangelands for which a plan has not been prepared and approved in relation to livestock feeding requires acquiring a grazing permit from the Ministry of Natural Resources and also observance of terms and conditions that are notified by the Ministry." In fact, according to this law, the rangeland management policy is determined by the government. According to Zohdi (2018), established in recent decades, the rules and regulations related to rangelands and rangeland management in Iran have an impact on rangelands and how they are used, and, on the other hand, they are the basis of the policies governing the management and government organization concerned and have a profound effect on the rangeland management system. Moeenedin (1994) states that since 1963 rangeland have been nationalized and individual ownership have been abandoned to the government and thus management evolves in the rangeland. This was taken on an immediate basis and did take into account the facilities and personnel or the creation of the necessary underlying culture. Ahmadi et al. (2011) state that "the law of the nationalization of forests and rangelands" is a major legal regulation and in which various issues have been referred to such as grazing of livestock in natural resources, requiring the stakeholders to obtain grazing permit from the FRWO during a one -year period, and the issue of excess number of livestock. Due to ambiguities, some legal provisions have an impact on the factors affecting the rangelands negatively and have led to increased degradation. Usefi et al. (2016) asserted that Article 3 of "the Conservation and Use of Forests and Rangelands Act" (adopted in 1967) is the first legal step in rangeland surveys and the issuance of permits, the first grazing conditions for livestock in rangelands were approved and on this basis in 1970 and notified by the government. Moeenedin (1997) states that the rangeland survey that was performed under specific social and political conditions in the 1980s, played a very important role in distorting the balance of livestock and rangelands. Abolhassani et al. (2013) indicated that since the adoption of "the Land Reform Act" and "the Nationalization Act of Natural Resources" in 1964, many reports have been published on intensifying the degradation of rangelands. In order to prevent further degradation of the rangelands, the government set some criteria for the systematic and careful use; however, these 
criteria were not properly implemented and accompanied the sudden increase in the number of livestock at the time.

\section{Rangeland management policies}

Baker and Eckerberg (2013) said that in general, a public policy may be defined as "a series of measures approved and followed by the state to solve a problem". In addition, the term "policy" can refer to a proposal or a set of specific measures that the government devotes to addressing a general problem. More precisely, the term "policy" means a formal proposal or operational plan that can be thought of as a centralized and executable tool that requires resource allocation. Zohdi (2018) state that it is not clear whether laws come before policies or they are adopted based on policies. However, what is certain is that they both affect each other. By signing the technical cooperation agreement in the framework of the Point Four Program between Iran and the United States on October 19, 1950, and taking into account the presence of experts from the US and some European countries for these programs, significant events occurred in relation to Iranian rangelands that were the basis of future developments or natural resources, especially the rangelands, of Iran. Since 1953, experts from the Point Four Program Organization have carried out extensive studies of agricultural systems, rangelands and rangeland management in Iran, which resulted in a widespread policy or plan for the Mohammad Reza Shah, called "the Shah and People Revolution", or "the White Revolution". The land reform policies, which include the nationalization of forests and rangelands in 1963, is one of the most important parts of this policy package, had a profound and significant impact on Iran's agricultural and rangeland management systems. Etemadi (1996) says "Despite numerous transient and local laws adopted about forests and rangelands over the past seventy years, the law of forests (adopted in 1943), the law of forests and rangelands (adopted in 1950), Act of Protection and Use of Forests and Rangelands (adopted in 1967) are recognized as milestones among the adopted laws. But the interesting point is that at every stage, a kind of political decision has been the basis for the preparation and adoption of a law. The law of Protection and Use of Forests and Rangelands, approved in 1967, was approved by the Cabinet of Ministers on the basis of a political decision approving the nationalization of forests and rangelands on January 17, 1963. The nationalization of forests and rangelands is the second out of the six principles of the political-economic and social developments of the 1960s. Four months after the final adoption of the Conservation and Exploitation Act, the Ministry of Natural Resources was formed with the merger of forestry, wildlife management, and aquaculture and fishery organizations. Fisher (2015) showed that in the years 1962 to 1966, Mohammad Reza Shah and the Council of Ministers adopted laws aiming at reforming Iran's social, political and economic structure. These reforms are generally known as "Six Point Reforms" or "Shah Revolution". The most important measures in this program were agricultural reforms and land management systems. As a result of these measures, large agricultural lands owned by a small numbers of Khans and landowners were divided among farmers and this was the reason for changing the lifestyle and social patterns of the country. In the following years, other policies were adopted by the government that directly or indirectly affected rangelands. Mashayekhi (1990) states that a major policy that was pursued in Iran was import increase of alfalfa to feed livestock and reduce the pressure on rangelands. Studies have shown that, from 1973 to 1984, alfalfa imports increased about ten times and this has been one of the reasons for the degradation of rangelands, because, with the increase in imports of 
alfalfa, the total supply of feed increased and livestock breeders increased the number of livestock. Then, the large population of livestock, especially in droughts, increased the pressure on rangelands. It was shown by the results that the total area of agricultural land increased by 50\%, from 6 to 9 million ha, after 1988. Under these conditions, despite the increase in total agricultural land, the amount of land allocated to forage production has decreased. Also, under the same conditions, the demand for food production in agricultural lands has been increasing, farmers moved their livestock to the rangelands and used extra lands for food production. Therefore, the pressure on the rangelands is increased. Eskandari et al. (2009) stated that, in order to reduce the pressure on the rangelands and increase the production of proteins, the most important policy adopted by the Ministry of Agriculture Jihad was the production of red meat in closed and industrial feedlots and changing the livelihood of rangeland owners. In addition, reforming the cropping pattern and increasing forage production, financial support, government facilities and land allocation have been other policies adopted by this ministry. On the other hand, some of the FRWO's policies for the systematic management of rangelands based on observance of criteria and terms included attraction of capital and knowledge in rangeland management, the provision of rangeland managers with their customary rights in order to reduce the number of small stockbreeders, increase of scientific and technical capacities of rangeland keepers and their role in rangeland management, land use systematization, conversion of lowproductivity farms into producers of forage, reduction of population exploiting the rangelands, balancing the number of livestock and rangelands, proper management in droughts, rangeland surveys, identification of common rights of livestock breeders, migration systematization, preparation and implementation of rangeland management plans, precipitation management, collection and production of seeds of quality crops, restoration and improvement of rangelands, insurance plans for rangeland management etc.

\section{Rangeland management plans}

Salmasi (1994) declares that the first scientific and technical measure in Iran in terms of rangeland management included the idea of reformation and use of rangelands based on Article 3 of "the Conservation and Use of Forests and Rangelands" (1967) which was the only legal tool for long-term exploitation of rangelands. In these plans, the main purpose was to reform, rehabilitate and properly utilize the rangeland. The first attempt at rangeland plans was made in 1969 with the preparation of extensive rangeland management plans. Since 1977, in the second attempt, experts focused on smaller units of operation, or in other words, the rangeland allotment. FRWO (2009) reported that despite the fact that scientific standards were followed in the establishment of large rangeland management projects, because of the large extent and lack of attention to customary areas and social issues, none of these plans were implemented. These plans were under focus till 1976. Large rangeland management plans were not successful for various reasons. Therefore, small projects were considered by the rangeland Technical Bureau (Government). Since 1976, the preparation and implementation of range plans were made in a new way and began with the emphasis on cooperation between the government and the stakeholders. Several rangeland plans were prepared from 1977 to 1979; however, out of 407 drafted designs, only 87 were approved, and only 30 were implemented, which indicates the failure and un-acceptance of such plans. The rangeland plans faced with a serious ignorance after the Islamic Revolution and they 
were nearly forgotten between 1980 and 1984, but in the years 1982 to 1984, a new attempt was made on large plans. During these years, plans such as forage crops were considered more seriously. In 1984, changes were made in the rangeland exploitation by changing the rangeland survey guidelines and the taking into account the livestock instead of humans (rangeland managers), in such a way that the growth of the stakeholder populations was observed from this year onwards. Since 1987, rangeland projects became part of FRWO's policies and were included as the main administrative program of the government for rangeland management. Also in this year, the duration of rangeland management projects increased from 15 to 30 years in order to increase the share of stakeholders. Composition of rangeland projects was gradually accepted as the main policy of rangeland management and is still the main policy of the state in managing rangelands. Zohdi (2018) state that the early rangeland management plans, prepared based on American schemes, and known as "large rangeland projects", continued until 1976, during which time, 24 projects were established on two million and five hundred thousand hectares and a huge attempt was made to rehabilitate the rangelands and strengthen the vegetation in the framework of these projects. Since 1977, rangeland projects became the main policy of managing rangelands in the framework of rangeland allotments known as "small projects". According to the latest report of FRWO, by August 2017, 14,651 range management projects have been prepared at 34,051,703 ha; of which, 13302 have been approved (31,804,989 ha), 8193 were outsourced and agreements were made with stakeholders as administrators $(19,781,615)$ and 5488 RMP $(14,671,245)$ are under construction. For every specific area, known as the rangeland allotment, these projects are prepared by consultant companies under the supervision of the government and implemented by the stakeholders as the administrators. Rangeland allotment contains a specific area of rangelands that has historically been exploited by an individual or a group of pastoralists, and its boundaries were determined by the surveying boards of the rangelands based on the documents provided by stakeholders and approved by the survey boards.

\section{Materials and methods}

The present study was conducted based on evaluation of rangeland management history in Iran and its effective factors. For this purpose, the principles of the subject were investigated by library studies and a review of scientific records and related documents. Based on the results of library studies, a questionnaire was prepared for attaining the expert opinions. Given the large number of rangeland experts were available and taking into account the type of the study, a non-probabilistic and judgment sampling method was used. Data from the survey via questionnaire were analyzed using SPSS software and the descriptive and inferential statistics of Chi square (X2) and Kruskal-Wallis test. The statistical population was divided into three main groups: 1. Rangeland management experts in the administrative area (experts from FRWO and Headquarters of the Natural Resources Departments of the Provinces); 2. Rangeland management experts in the research area; 3. Specialists, faculty members and $\mathrm{PhD}$ students in the area of rangeland management. The structure of the questionnaire was based on the results of library studies. This questionnaire is divided into three main sections: questions related to the personal profile of the respondent, questions related to the rules and regulations, and questions related to rangelands. In the rangeland and 
rangeland management section of the questionnaire, items related to government policies and plans are provided. A total of 268 questionnaires were completed and gathered in the present study. To verify the authenticity, validity and reliability of the items, the questionnaire was first distributed among a number of experts for a pilot test, and after revising its defects, the final questionnaire was designed. Finally, the validity of the questionnaire was verified by the Cronbach test.

\section{Results}

In order to study the results of this research, the items of the questionnaire were divided into 4 sections based on the assumptions of the research and the responses were analyzed using the statistical methods described above. The results are presented below.

\section{Respondents profiles}

From among 268 respondents, 233 were male and 35 were female. The highest number of females belonged to the provincial experts in the administrative area. Among the administrative experts, experts from 28 provinces participated in the study. The average age of retired experts of the rangeland office was 65.9 (oldest group) and the average age of the $\mathrm{PhD}$ student group was 34.1 years (youngest group). $71 \%$ of respondents aged 27 to 49 years old. Among the 268 respondents, 2 had diploma degree, 32 were undergraduates, 177 were graduates and 57 had doctoral degree $(\mathrm{PhD})$. In terms of academic rank, $177(66 \%)$ were experts, $34 \mathrm{PhD}$ students, 9 research instructor, 24 assistant professors, 16 associate professors, and 8 were faculty members and professors (Table 1).

Table 1. Personal characteristics of respondents

\begin{tabular}{c|c|c|c}
\hline Education & $(\boldsymbol{\%})$ & Gender & \\
\hline Diploma & 2 & Male & 233 \\
BSC & 32 & Female & 35 \\
MSC & 177 & & \\
PHD & 57 & & \\
\hline Total & 268 & & \\
\hline
\end{tabular}

\section{Evaluation of the results of the components of the rules and regulations}

Thirty one closed, multiple choice items are related to laws and regulations. The results analysis showed that among respondent groups, there is a significant difference in the order of $1 \%$ for responses given to the 31 studied variables. This is despite that there was less significant difference between the three main groups of respondents (academics and experts from the research section of FRWO), and that it is at the error level of $5 \%$ and confidence level of $95 \%$. In terms of gender, the difference in the responses was significant for only four items at the 5\% error level. The results of statistical analysis indicate that the effect of the respondents' education on the responses was significant at the error level of $5 \%$ for the 11 items (Table 2). 
Table 2. Results of evaluating the effectiveness of rangeland management rules and regulations

\begin{tabular}{|c|c|c|c|c|c|c|c|c|c|}
\hline \multirow{2}{*}{ Indicator } & \multicolumn{5}{|c|}{ Percent of responses } & \multirow{2}{*}{ Mean } & \multirow{2}{*}{ Mode } & \multirow{2}{*}{ St.D } & \multirow{2}{*}{ CV } \\
\hline & St.Ag (5) & Ag. (4) & Ne.(3) & Dis.(2) & St. Dis.(1) & & & & \\
\hline $\begin{array}{c}\text { The approval of the } \\
\text { nationalization of } \\
\text { forests and rangelands } \\
\text { (1963) had } \\
\text { effectiveness }\end{array}$ & 0.4 & 7.1 & 26.9 & 48.5 & 17.2 & 2.65 & 2.0 & 0.85 & 32.7 \\
\hline $\begin{array}{c}\text { Effectiveness of the } \\
\text { Law on the } \\
\text { Conservation and Use } \\
\text { of Forests and } \\
\text { Rangelands (1967) has } \\
\text { been positive }\end{array}$ & 0.4 & 33.6 & 45.9 & 17.9 & 2.2 & 3.27 & 3.0 & 0.73 & 22.32 \\
\hline $\begin{array}{l}\text { The rules are good for } \\
\text { managing rangeland }\end{array}$ & 3.0 & 28.4 & 19.0 & 40.7 & 9.0 & 2.76 & 2.0 & 1.05 & 38.04 \\
\hline The rules are deterrent & 1.5 & 22.8 & 45.9 & 23.5 & 6.3 & 2.90 & 3.0 & 0.88 & 30.34 \\
\hline $\begin{array}{c}\text { The rules are well } \\
\text { implemented }\end{array}$ & 0.4 & 3.4 & 38.1 & 39.6 & 18.7 & 2.27 & 2.00 & 0.81 & 35.68 \\
\hline $\begin{array}{c}\text { The rules are } \\
\text { consistent with } \\
\text { ecological conditions, } \\
\text { customary relations, } \\
\text { and socio-economic } \\
\text { issues }\end{array}$ & 0.0 & 6.3 & 19.4 & 63.8 & 10.5 & 2.47 & 2.00 & 0.68 & 27.53 \\
\hline $\begin{array}{c}\text { Rental ranges to other } \\
\text { ranchers are correct } \\
\text { and should be } \\
\text { regulated } \\
\end{array}$ & 0.7 & 9.8 & 23.9 & 36.9 & 28.7 & 2.40 & 2.00 & 0.98 & 40.83 \\
\hline $\begin{array}{l}\text { The rangeland survey } \\
\text { agenda is good and } \\
\text { effectiveness }\end{array}$ & 0.0 & 10.1 & 45.5 & 35.9 & 8.5 & 2.92 & 3.20 & 0.76 & 26.03 \\
\hline $\begin{array}{c}\text { Grazing in forests is } \\
\text { correct }\end{array}$ & 0.0 & 8.9 & 37.7 & 41.8 & 11.6 & 2.72 & 2.00 & 0.79 & 29.04 \\
\hline $\begin{array}{c}\text { Guild of livestock } \\
\text { breeders can be } \\
\text { important role in range } \\
\text { management } \\
\end{array}$ & 15.7 & 56.0 & 17.1 & 9.0 & 2.2 & 3.85 & 4.00 & 0.88 & 22.86 \\
\hline $\begin{array}{c}\text { The rules and } \\
\text { regulations concerning } \\
\text { rangeland need to be } \\
\text { reviewed }\end{array}$ & 20.1 & 60.5 & 16.9 & 1.8 & 0.7 & 4.12 & 4.00 & 0.65 & 15.78 \\
\hline
\end{tabular}

St.Ag (Strongly Agree), Ag. (Agree), Ne. (Neutral), Dis. (Disagree), St.Dis (Strongly Disagree), St.D (Standard Deviation), CV (Cofficent of Variation), A.S.R (Average Score of Response)

The analysis of responses has shown that a large number of respondents believe the approval of nationalization of forests and rangelands in 1963 did not have a positive effect on rangeland and rangeland management. Also, more than $50 \%$ of the responses consider the implementation of the above-mentioned resolution as weak or very weak. Therefore, based on the results, the research hypothesis regarding the positive 
effectiveness of the nationalization of forests and rangelands is rejected. In connection with the conservation and use law of forests and rangelands (adopted in 1967), the results show that it had a more positive and better effect on rangelands than the nationalization law. Respondents believe that this is a better and more comprehensive law than the nationalization law of forests and rangelands. However, a significant proportion of experts did not provide their opinion in this regard, but at the same time, a large proportion of respondents still do not take the law of protection and use of forests and rangelands as a comprehensive one. The results of this research show that about $50 \%$ of respondents believe that approved laws do not meet the requirements of principal management and the others do not consider the rules deterrence appropriate. More than 58\% of participants in the research believe that the rules are not being implemented correctly and completely. A significant proportion of respondents (more than $74 \%$ ) believe that rules related to rangeland management with ecological condition, Conventional relations and social and economic issues have low consistency. Nowadays, many rural councils and some livestock breeders who do not have livestock equal to the number of livestock in Grazing Permit (GP) or Rangeland Management Plan (RMP), Ranges are rented to maintain their privilege and privilege for the purpose of income from this area. In this regard, more than $65 \%$ of the experts oppose the lease and regulation of the rangeland.

Reviewed and notified several times so far, the rangeland survey agenda is one of the most important provisions of rangeland management and is the main basis for rangeland surveys. Examination of the results of this agenda declares that a significant number of experts believe that this agenda does not conform to the common user relations and cannot solve the problems of small stakeholders. Also, about 52\% of respondents believe that this agenda cannot establish a balance between livestock and rangeland. In contrast, more than $44 \%$ of experts believe that the rangeland survey agenda can pave the way for the participation of stakeholders in the determination of the rights to rangeland management. While nearly $61 \%$ of respondents take the role of rangeland survey in rangeland management as a positive role, more than $79 \%$ of the experts agree with the revision and updating of the guidelines. The results showed that many experts disagree with the issuance or extension of grazing permits in forests. In total, more than 44 percent of respondents consider the effectiveness of the above guidelines very low and more that 45 percent did not have an opinion about this issue. More than $71 \%$ of the experts participating in this research consider the role of Guild of livestock breeders, managing pastures and more useful implementation of positive rules. An important point about rules and regulation related to pastures management is that, over $80 \%$ of respondents believe that the rules and regulations need to be reviewed and updated, and only $2.5 \%$ oppose this claim.

\section{Evaluation of the analysis results of the components related to government policies and programs for rangelands management}

In this section of the research, a total of 35 items were used based on the content and objectives, which is grouped and analyzed according to the content and purpose of Table 3.

As the analysis of the result of study in Table 3 shows, more that $57 \%$ of respondents believe that plant coverage and the balance of livestock and pasture have been better in the last 3-4 years, in contrast, only 9.5\% have opposed this issue. Also, $66.5 \%$ of 
participants in the study said that the rate of land use change in the past was less than 2017.

Table 3. Results of the evaluation of the effectiveness of government policies, plans and programs related to rangeland management

\begin{tabular}{|c|c|c|c|c|c|c|c|c|c|}
\hline \multirow{2}{*}{ Indicator } & \multicolumn{5}{|c|}{ Percent of responses } & \multirow{2}{*}{ Mean } & \multirow{2}{*}{ Mode } & \multirow{2}{*}{ St.D } & \multirow{2}{*}{ CV } \\
\hline & St.Ag (5) & Ag. (4) & Ne.(3) & Dis.(2) & St. Dis.(1) & & & & \\
\hline $\begin{array}{l}\text { Rangeland vegetation } \\
\text { and equilibrium of } \\
\text { livestock and rangeland } \\
\text { in the past ( } 30 \text { to } 40 \\
\text { years ago) have had } \\
\text { better health }\end{array}$ & 7.1 & 50.0 & 33.7 & 7.6 & 1.9 & 3.88 & 4.00 & 0.71 & 18.30 \\
\hline $\begin{array}{c}\text { Land use change and } \\
\text { Grazing pressure has } \\
\text { been greater in the past } \\
(30-40 \text { years ago })\end{array}$ & 1.1 & 7.1 & 25.3 & 44.1 & 22.4 & 2.34 & 2.00 & 0.91 & 38.9 \\
\hline $\begin{array}{c}\text { The great range } \\
\text { management plan } \\
\text { (RMP) that were } \\
\text { planing from } 1969 \text { to } \\
1976 \text { were good plans }\end{array}$ & 4.9 & 14.9 & 49.6 & 28.4 & 2.2 & 3.08 & 3.00 & 0.84 & 27.27 \\
\hline $\begin{array}{l}\text { Management of rural } \\
\text { and non-rural } \\
\text { rangelands requires a } \\
\text { different pattern } \\
\end{array}$ & 24.6 & 63.1 & 9.3 & 3.0 & 0.0 & 4.09 & 4.00 & 0.67 & 16.38 \\
\hline $\begin{array}{l}\text { Positive Effectiveness } \\
\text { of Rangeland } \\
\text { Management Plan on } \\
\text { Vegetation } \\
\text { Improvement, Ranchers } \\
\text { Earnings, Livestock } \\
\text { Balance and Range and } \\
\text { Participation of } \\
\text { ranchers } \\
\end{array}$ & 3.4 & 20.1 & 43.3 & 26.1 & 7.1 & 3.24 & 4.00 & 0.84 & 25.93 \\
\hline $\begin{array}{c}\text { Range management } \\
\text { Plan are a good pattern } \\
\text { for rangeland } \\
\text { management }\end{array}$ & 0.0 & 5.2 & 44.4 & 40.4 & 10.0 & 2.8 & 3.2 & 0.68 & 24.3 \\
\hline $\begin{array}{c}\text { For manage Rangeland } \\
\text { under camel Grazing, } \\
\text { needs a special pattern }\end{array}$ & 7.8 & 48.1 & 38.0 & 5.6 & 0.4 & 3.65 & 4.00 & 0.71 & 19.45 \\
\hline $\begin{array}{c}\text { Range management } \\
\text { Plan are a good pattern } \\
\text { for Rangeland under } \\
\text { camel Grazing } \\
\end{array}$ & 0.0 & 4.1 & 51.1 & 29.5 & 15.3 & 2.44 & 3.00 & 0.80 & 32.8 \\
\hline $\begin{array}{l}\text { The framework of } \\
\text { RMPs should be } \\
\text { appropriate to } \\
\text { ecological conditions }\end{array}$ & 41.0 & 50.4 & 7.1 & 1.1 & 0.4 & 4.31 & 4.00 & 0.68 & 15.78 \\
\hline $\begin{array}{l}\text { The government has } \\
\text { been successful in } \\
\text { managing rangeland }\end{array}$ & 0.0 & 3.0 & 36.2 & 42.5 & 18.3 & 2.50 & 3.50 & 0.82 & 32.8 \\
\hline
\end{tabular}




\begin{tabular}{|c|c|c|c|c|c|c|c|c|c|}
\hline $\begin{array}{l}\text { RMPs need to be } \\
\text { updated }\end{array}$ & 16.0 & 60.8 & 19.1 & 3.7 & 0.4 & 4.03 & 4.00 & 0.68 & 16.87 \\
\hline $\begin{array}{c}\text { The Iranian } \\
\text { government's policies } \\
\text { for managing rangeland } \\
\text { need to be updated }\end{array}$ & 42.2 & 47.8 & 7.8 & 1.9 & 0.4 & 4.30 & 4.00 & 0.72 & 16.74 \\
\hline $\begin{array}{c}\text { The quality of } \\
\text { monitoring of RMPs is } \\
\text { good at the county, } \\
\text { provincial and national } \\
\text { levels }\end{array}$ & 0.0 & 1.1 & 23.1 & 47.4 & 28.4 & 2.28 & 2.00 & 0.68 & 29.8 \\
\hline $\begin{array}{l}\text { Seed production } \\
\text { stations are of great } \\
\text { importance in the } \\
\text { improvement and } \\
\text { rehabilitation of } \\
\text { rangelands }\end{array}$ & 14.6 & 48.1 & 23.9 & 11.6 & 1.9 & 3.62 & 4.00 & 0.93 & 25.70 \\
\hline $\begin{array}{c}\text { Stations of seed } \\
\text { production of rangeland } \\
\text { plants are well managed }\end{array}$ & 0.0 & 15.3 & 16.0 & 50.0 & 18.7 & 2.28 & 2.00 & 0.94 & 41.23 \\
\hline $\begin{array}{l}\text { Economic factors play } \\
\text { an important role in the } \\
\text { participation of } \\
\text { livestock breeders in the } \\
\text { management of } \\
\text { rangelands }\end{array}$ & 46.6 & 48.1 & 3.7 & 1.5 & 0.0 & 4.40 & 4.00 & 0.64 & 14.54 \\
\hline $\begin{array}{c}\text { Range management } \\
\text { Plan in the current } \\
\text { situation are not a good } \\
\text { policy for managing } \\
\text { rangelands }\end{array}$ & 22.0 & 47.8 & 14.9 & 13.4 & 1.9 & 3.75 & 4.00 & 1.01 & 26.93 \\
\hline
\end{tabular}

St.Ag (Strongly Agree), Ag. (Agree), Ne. (Neutral), Dis. (Disagree), St.Dis (Strongly Disagree), St.D (Standard Deviation), CV (Coefficient of Variation), A.S.R (Average Score of Response)

More than $50 \%$ of the respondents did not provide any opinion about the large RMPs that were produced in Iran between 1969 and 1976, and about 30\% of them considered the Plans as good ones. More than $88 \%$ of rangeland specialists believed that management of different types of rural and non-rural rangelands need different schemes, while $41 \%$ opposed to the fact that current RMP are good models for managing rangelands. Anyhow, 33\% agree with this statement and 25\% did not give any opinion. In contrast, more than $45 \%$ of respondents believe that current RMPs provide good models for nomadic rangeland management, to which only $29 \%$ opposed. About $82 \%$ opposed to the following statement: "the current framework of rangeland management plans is intact and comprehensive"; which indicates the disapproval of the framework for these projects by the respondents of the study. Results regarding the positive effectiveness of RMPs on improving vegetation, livestock and rangeland balance, income of rangers and their further participation show that more than $33 \%$ did not evaluate it positively, and only $23 \%$ consider positive impact for RMPs. However, more than $43 \%$ did not have any point of view regarding this issue. A large number of respondents believe that rangelands under camel grazing have special conditions and require a specific management model. One of the problems encountered in RMPs is that 
these are one prescription for all different conditions. Over $91 \%$ of the respondents believe that "the framework of RMPs should be adapted to ecological and managerial conditions". Also, a large number of respondents agree with the utilization of medicinal plants and industrial plants in the rangelands, and believe that this may help the economy of rangeland management. Most respondents (over 90\%) said that "the rangeland management policies of the FRWO have to be improved and upgraded according to the changing situations". Also, 67\% stated that "as the rangeland management plans are not suitable for the current rangeland management", to which only $14 \%$ opposed. The results show that only $6 \%$ of respondents believe that there is a good quality for the supervision of natural resource departments of the counties and provincial offices on rangelands and RMPs, and this figure declines to $3.3 \%$ for the FRWO. Over $70 \%$ of the respondents chose the "weak" and "very weak" scales for the FRWO's supervision. More than 55\% of the experts stated that the legal proceeding of natural resource departments against the offenders is "appropriate to some extent" and $7 \%$ find these measures "appropriate". More than $48 \%$ believe that the supervision by the Rangeland Issues Bureau is "weak" or "very weak". Over $62 \%$ of the respondents think that the stations producing the grassland seeds are of high importance, but a large number of the respondents (more than 68\%) believe that these stations have not been properly managed in recent years. More than $78 \%$ of respondents believe that FRWO had "little" or "very little" success in managing rangelands, and $17.5 \%$ said that the FRWO has not been successful at all. So the total proportion of specialists who considered the FRWO is unsuccessful in rangeland management was 96\%. In this regard, more than $64 \%$ of respondents stated that the policies of FRWO were not effective in managing rangelands. The results of Kruskal Wallis test on rangeland management and policymaking data (Table 3) show that at an error level of 5\%, different groups of respondents (from experts FRWO, Natural resources research specialist and university faculties) made significant differences in 15 items, gender and educational level in 4 items, scientific rank in 8 items, Education in 6 items show that at an error level of 5\%, different.

\section{Discussion}

Basically, based on their core strategies, governments define executive policies in each sector and, proceed with the implementation of relevant laws in order to regulate these policies and their enforcement. The management of natural resources and lands in each country is influenced by the large-scale policies and the general approach of governments. In Iran, in the late 1950s and early 1960s, important improvements were made in the agricultural and land management fields, nationalization of forests and rangelands. For the management of renewable natural resources, especially rangelands, as major rulings, the Nationalization of Forests and Rangelands (1963) and the Protection and Use Act (1967) are now five decades old. National rangelands were established and the rangeland management structure and related organizations were formed according to these two laws. The results of this research have shown that, for various reasons, a large number of the respondents believe that "the nationalization of forests and rangelands" in 1963 had no positive effects on the rangeland management system due, primarily, to the fact that its implementation mechanisms were not provided or properly implemented. But, In contrast, a large number of audience were in the belief that "the Law on the Conservation and Use of Forests and Rangelands" in relation to 
rangeland management was better and more complete than "the nationalization of forests and rangelands". The results showed that, as most respondents indicated, Existing laws and regulations are not concordant with ecological facts, customs, social relations, and social and economic issues. Most of the surveyed statistical population believed that the rules and regulations are weak in implementation. Also, 90\% of respondents have emphasized the need to review the relevant laws and regulations. These results are consistent with those of Shamekhi (1992), Salmasi (1994), Azkia (1997), Moeenedin (1994, 1997, 1998), Abdolahpour (2001), Farvar (2005), Eskandari et al. (2009) and Abolhassani et al. (2013). In addition the results indicated that the rangeland survey agenda is not acceptable for the establishment of the balance between the livestock and rangeland and needs to be seriously revised. Moeenedin (1998), Abdolahpour (2001), and Abolhassani et al. (2013) obtained similar results. The above mentioned agenda plays an important role in the determination of the rights of livestock breeders and the establishment of a balance between the livestock and the rangeland; so, it is necessary to be upgraded according to the changes and current conditions. Related to the laws of rangeland management in Turkey, Koc et al. (2014) states that in 1998, the Turkish Parliament approved a rangeland law that empowered the central government to adjust the season of grazing, grazing capacity, to improve the rangelands, and to take other measures to control the use of rangelands. In the present day Turkey, the rangelands of the Republic of Turkey are dedicated to the villages and each village has a right for grazing. Owners of domestic animals in many of these villages still apply the Chergasht (immigration for grazing) method, and in some cases some groups act similar to their predecessors. For the United States, Larson-Praplan (2014) states that one of the first laws approved in relation to rangeland management was the Homestead Act, signed and endorsed by President Abraham Lincoln in 1862. Later, in 1880s, several rules for the management of California rangelands were created. The laws approved in the 1970s have had a great impact on rangeland management. Also, in 1978, the rangeland improvement law was approved and the Clean Water Act was also a part of other related laws that were adopted in this decade. As stated by Holechek (1981), one of the most important events associated with rangeland management was the adoption of the Taylor Grazing Act in 1934, according to which the public land management was assigned to the state-owned grazing service. In response to the pressure of environmental groups, the National Environmental Policy Act was approved by the Congress in 1969. Feller (1998) states that since 1993, significant progress has been made in the field of laws, regulations, standards and guidelines for livestock grazing in public lands of the western US states. Following a two-year attempt, amendments were made to the legislation on grazing and the issuance of permits in 1995. In China, as Peter Ho (2000) indicated, the rangeland law was passed in 1985, through which the rangeland management policy was recognized officially and determined the rights and responsibilities of the government and livestock breeders. According to this law, livestock breeders who were permitted to use grasslands were required to guarantee long-term utilization of the rangelands. In the case of Mongolia, Hannam (2014) states that, according to the law approved in 1992, all lands are stateowned. Mongolia's environmental law system was supposed to achieve goals of environmental policies based on environmental protection laws in 1995. Mongolia's environmental law system does not have the ability to effectively manage the major environmental problems in the country. It should be noted, however, that since 2011, the Mongolian government has begun a comprehensive environmental law review. The 
study of the status of rules related to rangelands management in several countries indicates the evolutionary trend in the implementation and enforcement of the above laws in these countries. In recent decades, many countries have been trying to update natural environment laws in line with changes in ecosystems, exploitation communities, climate change, and international achievements derived from important environmental conventions.

Historically, local breeders used grassland cover on the forest floor in the northern forest (Hirkani) and Zagros forests as pasture. Many experts believed that the presence of livestock in forests is one of the most important factors in destroying and preventing natural regeneration of forests, so they emphasized that permit should not be issued for grazing in forests. Therefore, as rangeland management experts, many respondents in this study oppose the issuance and extension of the permit. In addition, due to poor government supervision and the migration of a large part of the villagers to cities, Islamic councils that are responsible for managing rural rangelands in most villages, rangelands that do not have a local livestock breeders are given to other, which is illegal the rangeland survey agenda. But, many experts believe that, given the high frequency of the phenomenon in many parts of the points of the country, it is necessary for the government to organize it. A significant proportion of research respondents opposed leasing of rangelands, while a large number advocated organization of the phenomenon. Currently, permits for medicinal plants, ecotourism, beekeeping, etc. are issued for a variety of individuals who are not generally administrating the rangeland plans. The results have shown that most experts believe that these permits should be issued in the form of a rangeland management plan and only for the administrator. Another important point is that rangeland plans have a single model in all circumstances, while many respondents stated that there should be different plans for in rural and non-rural, ecologically different and camel rangelands. Many experts think that there are problems in rangeland management framework which should be solved. Iran is a country with a diversity of ecological conditions that require different patterns of management. However, the framework for rangelands is the same for all ecological conditions. The results have shown that more than $90 \%$ of the respondents of the questionnaire believe that "the framework of rangeland projects should be designed according to ecological and managerial conditions." This is a very important issue to consider in policy making and designing management plans. A total of $90 \%$ of the rangeland experts believe that "FRWO policies on rangeland management must be adapted to the conditions." Also, the results indicate that many experts believe "Rangeland management plans as rangeland management policy in the present situation, do not address rangeland management" and a significant number of the audience said in this study that the FRWO was not successful in rangeland management. These are consistent with the results of Alizadeh and Mahdavi (2007), Mirdeylami and Moradi (2017). Regarding RMPs, Amiri Maleki et al. (2009) stated that in general, the implementation of RMPs in the summer rangelands has been very successful, but it has not been successful - and has been deteriorating sometimes - in winter rangelands due to extended implementation time, early grazing, numerous usages, and being positioned in rural areas. In addition many studies have shown that implementation of RMPs is generally better than lack of any plans for the rangelands. In this regard, Dehdari et al. (2014) state that in rangelands with a plan due to the safety of the land owners regarding the ownership of the rangeland and more control of the governmental systems, are less than conflict between the land owners of one rangeland or nearby ranges. Also, the 
implementation of rangeland management plans in rangeland allotments has improved the conditions of the rangelands. Based on the obtained results, Eftekhari et al. (2016) state that there is a significant difference at the error level of $1 \%$ between the rangelands for which plans have been implemented and others; the major reason being observance of management principles such as the time of arrival and departure of livestock, the optimal distribution of livestock in the rangeland and the relative realization of livestock and rangeland balance in these rangelands.

Depending on the ecological conditions of rangeland ecosystems and the social characteristics of the stakeholders, different countries apply different policies to reduce the degradation of rangelands, each having different advantages and disadvantages. Hannam (2014) states that due to the ecological hazards that have been caused by the unplanned exploitations, a comprehensive plan has been implemented by the Mongolian government since 2011 to update environmental laws and regulations. Due to the degradation of the Turkish rangelands, being aggravated from 1950s and continued until the 1980s, Koc et al. (2014) believe that excessive grazing has caused a major concern for degradation of rangelands and soil erosion. Therefore, in the year 1980, the Turkish government identified about 14 million ha of severely degraded lands and began to amend and rehabilitate these lands by subsequent laws (such as the 1998 rangeland law). YanBo Li et al. (2014) state that in China three major rangeland management policies have brought about major changes in livestock numbers and rangeland ecosystems: Rangeland Household Contract System (RHCS), Ecological construction projects (ECPs) and Herder Settlement Policy (HSP). The implementation of these policies provided major modifications to rangeland management systems. In the mid1980s, RHCS began in Chinese major herding areas, and is currently used in the six main provinces of northwestern China. By 2011, this policy covered about $79 \%$ of China's exploitable rangelands. Gongbuzeren et al. (2015) state that, over the past 30 years, the Chinese government linked three main policies of the Rangeland Household Contract Policy (RHCP), the Nomad Settlement Policy (NSP), and the RAPs (Rangeland Ecological Construction Projects) to manage the rangelands. These policies have caused great changes in rangeland communities as well as rangeland ecosystems. Many studies have shown that RHCP policy has had a significant negative impact on rangeland management and ecosystems. This is despite that the nomadic system for the exploitation of rangelands evolved over time and has been consistent with the unsustainable environmental conditions of the rangelands. It is also true that NSP policy has had a few positive impacts on livelihood, but most studies have shown major negative impacts of this policy on rangeland ecosystems. Also, studies have shown that RECPS policies have had positive effects on the restoration and regeneration of rangeland ecosystems, but have made negative effects on livelihood of rangeland managers. In general, it can be argued that making changes in any of the components of rangeland ecosystems or the stakeholder communities could lead to changes in other components. Therefore, we have to look for a SES (social-ecological systems) system based on which we can balance social and ecological factors. Government policies in the mentioned countries have had a different impact on rangeland ecosystems and stakeholder communities, but the important point is that ongoing studies are examining the effects of these policies in a continuous manner, that can be very effective in improving and reforming policies and management practices. 


\section{Conclusion}

The study of the above-mentioned sources indicates that rangeland management legislation in Turkey, Mongolia and China has not long been a long history, but a few decades ago, but it has evolved and governments are trying to update it. In the United States, the rules for managing rangelands have a longer history and evolved in an evolutionary process with changes in rangeland ecosystems and utilizable communities. The results of this research have shown that there is no specific rule for rangeland management in Iran, and the legal rules of rangeland have been seen in the general framework of the laws of natural resources management. In the past 50 years, despite the many changes in rangeland ecosystems and utilitarian communities, these rules have not been revised and updated. On the other hand, despite the numerous and parallel rules and the poor implementation of the relevant laws, the effectiveness of the rules related to management and conservation of rangelands has greatly decreased. Therefore, due to the wide variation in the level and quality of the rangeland and the changes that have been made in the exploiting communities and the climate change that has been increasing in the Middle East region, it is necessary to complete and update the laws related to the management of rangeland ecosystems. Also, given the international obligations created, these laws must also be in line with these obligations. Another important point in relation to the rules of rangeland and the effectiveness of existing laws is the low and inadequate studies and studies in this area that show the need for comprehensive and in-depth reviews on this issue.

In conjunction with government policies and programs, the results of this study have shown that policies will come at a time when they are consistent with the ecological, social, and economic realities of the day, and that they can be fully implemented. However, in some cases, due to the lack of a clear strategy in the management of natural resources and the change of government, the government's priorities in the management of natural resources and land changed frequently and the continued implementation of the principled policies with has encountered a problem. The research confirms that rangeland specialists believe that policies, management patterns and plans should be tailored to ecological conditions and social characteristics of operators, which is absolutely necessary in a country with a high ecological and social diversity in Iran. Therefore, based on the accurate and updated data of the strategic plan for management of rangelands, we must prepare and implement the ecological diversity and social features of different areas. On the other hand, the government should regulate and define its macro policies in line with the sustainability of natural ecosystems. To achieve this, it is necessary to carry out extensive and in-depth research into the impacts of policies on rangeland management and other natural ecosystems, as well as comprehensive studies on the updating of ecological, social and economic data. In addition, with the presence and cooperation of international institutions, the experiences of other countries that have succeeded in managing rangelands and legislation for natural ecosystems.

\section{REFERENCES}

[1] Abdolahpour, M. (2001): The Balance of Livestock and Rangeland or the Balance of Farmer and Rangeland? - The Second National Conference of Range and Range Management in Iran, pp. 54-63. 
[2] Abolhassani, L., Oesten, G., Rajmis, S., Azadi, H. (2013): Attitudes of rangeland holders towards sustainable range management in Iran: a case study of the Semnan rangelands. The Rangeland Journal 35: 435-443.

[3] Ahmadi, S., Barani, H., Aghili, S. M., Sepehri, A., Khaje, S. G. (2011): The analysis of law nationalize of forests and rangelands and its possible effects on rangelands degraded. - The Second National Conference on Combating Desertification and Sustainable Development of Desert Wetland Iran, pp. 210-213.

[4] Alizadeh, A., Mahdavi, F. (2007): Evaluating and reviewing the views of the implementers of range management plans on the important issues of balance livestock and rangeland plan. - Journal of Forest and Rangeland 72-73: 13-20.

[5] Amiri Maleki, A. R., Kamali, M., Mohammad Beighi, J. (2009): The effect of range management plans on production, trend and condition of rangeland (case study of Qazvin Province). - Journal of Forest and Rangeland 79-80: 69-73.

[6] Araghi, S. E., Karimi, A., Ghamami, M., Taghizadeh Ansari, M., Shams, A. (1998): Comparative Study of the Laws System of Forests and Rangelands. - Institute of Comparative Law of Tehran University Faculty of Law and Political Science, Tehran.

[7] Azkia, M. (1997): Social dimensions of range management in Iran (with emphasis on Fars and Kohgiluyeh and Boyerahmad Provinces). - Journal of Social Sciences 8: 1-23.

[8] Baker, S., Eckerberg, K. (2013): A policy analysis perspective on ecological restoration. - Ecology and Society 18(2): 17.

[9] Dehdari, S., Arzani, H., Movahed, H., Zare Chahouki, M. A., Shaban Ali Fami, H. (2014): Comparison of rangelands with/without Range Management Plan (RMP) using application of Analytical Hierarchy Process (AHP) in Semirom. - Iranian Journal of Range and Desert Research 21(3): 383-393.

[10] Eftekhari, A. R., Arzani, H., Zandi Esfahan, E., Alizadeh, E. (2016): Effect of range management plan on range condition (Case study: Zarandieh region, Markazi province) . - Iranian Journal of Range and Desert Research 23(2):209-218.

[11] Eskandari, N., Alizadeh, A., Mahdavi, F. (2009): Range Management Policies in Iran. Forest, Rangeland and Watershed Management Organization, Tehran.

[12] Etemadi, S. U. (1996): Legitimacy of Nature and Natural Resources Law. - Journal of Forest and Rangeland 29: 6-15.

[13] Farahpour, M., Marshall, H. (2001): Background Paper for the Launching Meeting for the Asian Thematic Programme Network on Rangeland Management and Sand Dune Fixation (TPN3). - Yazd, Iran.

[14] Farvar, M. T. (2005): The Qashqai: Nomadic Pastoral Livelihoods. Against All Odds. Sharing Power, Learning by Doing in Co-Management. - IUCN, Gland.

[15] Feller, J. M., (1998): Recent developments in the law affecting livestock grazing on western riparian areas. - Wetlands 18(4): 646-657.

[16] Fisher, W. B. (2015): The Cambridge History of Iran. Chapter 21: Land Reform in Iran, pp. 684-714. - Cambridge University Press, Cambridge.

[17] Forest, Rangeland and Watershed Management Organization (FRWO) (2009). 30 Years Performance of "Forest, Rangeland and Watershed Management Organization". An overview on the experiences of the organization in the rangelands section. - Puneh Publishing.

[18] Gongbuzeren, A., Li, Y., Li, W. (2015): China's rangeland management policy debates: What have we learned? - Rangeland Ecology \& Management 68: 305-314.

[19] Hannam, I. (2014): Legal and Policy Aspects of Rangeland Management: Mongolia. Australian Centre for Agriculture and Law University of New England, Armidale, Australia.

[20] Holechek, J. L. (1981): A brief history of range management in the United States. Rangelands 3(1): 16-18.

[21] Holechek, J. L., Pieper, R. D., Herbel, C. H. (2004): Range Management: Principles and Practices $\left(6^{\text {th }}\right.$ Edition). - Pearson Prentice Hall, Upper Saddle River, NJ. 
[22] Javanshir, K. (1999): History of the Natural Resource Sciences of Iran. - Agricultural Research, Education and Extension Organization. The Academy of Sciences of I. R. Iran Department of Agricultural Sciences, Tehran.

[23] Karimi, K., Karami Zehkordi, E. (2016): Factors affecting rangeland destruction from the viewpoint of rural utility (case study in Mahnashan County). - Journal of Forest and Rangeland 105: 37-43.

[24] Koc, A., Schacht, W. H., Erkovan, H. I. (2014): The history and current direction of rangeland management in Turkey. - Rangelands 37(1): 39-46. DOI: 10.1016/j.rala.2014.12.005.

[25] Larson-Praplan, S. (2014): History of rangeland management in California. - Rangelands 36(5): 11-17. DOI: http://dx.doi.org/10.2111/Rangelands-D-14-00020.1.

[26] Mashayekhi, A. N. (1990): Rangelands destruction under population growth: the case of Iran. - System Dynamics Review 6(2): 167-193.

[27] Moeenedin, H. (1994): Historical of Rangeland and Ownership in Iran. - The First National Conference of Range and Range management in IRAN, pp. 99-114.

[28] Moeenedin, H. (1997): Rangeland and law. - Journal of Forest and Rangeland 37: 16-28.

[29] Moradi, E., Mirdeilami, S. Z. (2017): Iranian Rangeland Management Systems (Along with the Overall Look at the Pastures of the World). - Jihad University of Isfahan Industrial Publishing Center, Isfahan.

[30] Motamedi, G. R., Heidari, G. R. Vajihezadeh, G. A. (2007): Laws and Regulation Collection of Ministry of Agriculture. - Behnami Publications, Tehran.

[31] Salmasi, J. (1994): An overview of the range management in Iran (Part I, II). - Journal of Forest and Rangeland 20: 10-18.

[32] Shamekhi, T. (1992): People and Natural Resources. - Journal of Forest and Rangeland 10:21-24.

[33] Shamekhi, T. (2009): Laws and management of natural resources (forest and meadows). Tehran University, Tehran, pp. 7-15, 109-110.

[34] Squires, V. R., Shang, Z. H., Ariapour, A. (2017): Rangelands along the Silk Road (Transformative Adaptation under Climate and Global Change). - In: Ariapour, A., Badripour, H., Jouri, M. H (eds.) Rangeland and Pastureland in Iran: Potentials, Problems and Prospects, Chapter 7. Nova Science Publishers Inc., Hauppauge, NY.

[35] Usefi, H., Saeedizadeh, R., Mir, Z., Fadaii Moghadam, A. (2016): Collection of rules and regulations of natural resources (explanatory and Corrected). - ShapourKhast Publishers, Khorramabad, pp. 39-43.

[36] YanBo, L., Gongbuzeren, A, WenJun, L. (2014): A review of China's Rangeland Management Policies. - Drylands and Pastoralism, Country Report.

[37] Zohdi, M. (2018): Range Management Analysis and Offer of Strategic and Effective Pattern (Taleghan Watershed). - PhD Thesis Science and Research Branch, Islamic Azad University, Iran. 